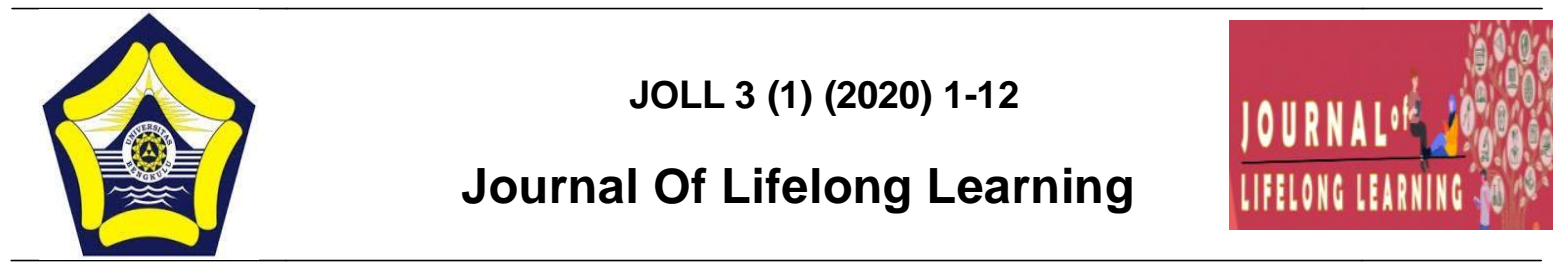

\title{
Pemahaman Pendidikan Nonformal
}

Devina Wliyana Arief', Sopino, Ririn Gusti ${ }^{3}$

1DevinaWliyaa,Universitas Bengkulu,Indonesia, devinaarief100@gamail.com

${ }^{2}$ Sofino Universitas Bengkulu,Indonesia, sopino@gmail.com

${ }^{3}$ Ririn Gusti.UniversitasBengkulu.riringusti88@gmail.com

\section{Abstract}

The purpose of this research is to describe understanding by new students of nonformal education at Bengkulu University about nonformal education. As for the scope studied in this research was students understanding about the scope nonformal education which consist of understanding, characteristics, goals, roles, programs, institution and education facilities. Furthermore, reviewing the understanding of students at bengkulu university about the graduate competence and employment opportunity of S1 non formal education. The design of this research was descriptive quantitatif research, this method carried out with the main goal to make an idea of situation objectively, the respondents of this research were new students of nonformal education study program at Bengkulu University. The result and discussion of this research that understanding of new students of nonformal study program at Bengkulu University about scope of informal education was high enough with percentage $69.4 \%$, understanding about the graduate competence of S1 non formal education was sufficient with percentage $51 \%$ and understanding about employment opportunity of S1 non formal education was highwith percentage $67.5 \%$

Key words : understanding, students, nonformal education 


\section{PENDAHULUAN}

Pendidikan di pandang sebagai hal yang sangat penting bagi kemajuan hidup seseorang, semakin tinggi pendidikan seseorang, maka masyarakat akan lebih menghargai orang tersebut. pendidikan penting sebagai bekal untuk masa depan anak dan bangsa.Oleh karena itu, pendidikan tidak dapat dianggap sepele, Pendidikan merupakan kebutuhan dasar manusia yang harus terpenuhi, maka dari itu pemerintah mengatur hal ini sedemikian rupa, baik dalam aturan undang-undang maupun kebijakan-kebijakan agar setiap individu berhak dan mendapatkan pendidikan. Banyak lembaga yang menjadi tempat khusus untuk memberikan sebuah pendidikan, contohnya seperti sekolah mulai dari pendidikan dasar, pendidikan menengah pertama, dan pendidikan menengah atas,organisasi, lembaga kursus dan pelatihan serta perguruan perguruan tinggi dan banyak lembaga lainnya.

Perguruan tinggi ataupun universitas menjadi wadah para pemuda pemudi untuk membentuk karakter serta kepribadian nya ke lebih dewasa lagi. Saat memilih jurusan tak jarang calon mahasiswa hanya asal memilih jurusan tanpa melihat minat dan bakat yang sesuai dengan yang dimiliki, Sehingga banyak mahasiswa merasa salah masuk jurusan. Hal ini kerapkali terjadi di kalangan mahasiswa baru, salah satunya terjadi di program studi pendidikan non formal di Universitas Bengkulu. Secara umum tujuan penelitian ini adalah untuk mengetahui bagaimana Pemahaman mahasiswa baru tahun 2018 tentang program pendidikannonformal di universitas Bengkulu. Sedangkan tujuan penelitian secara khusus adalah : 1) Mendiskripsikan pemahaman mahasiswa baru tentang ruanglingkup pendidikan nonformal pada Universitas Bengkulu. 2) Mendiskripsikan pemahaman mahasiswa baru tentang kompetensi yang diperoleh lulusan pendidikan nonformal. 3) Mendiskripsikan pemahaman mahasiswa baru tentang kesempatan kerja dalam pendidikan nonformal.

Pendidikan berlangsung sepanjang hidup atau seumur hidup, nilai dari awal lahirnya seseorang hingga akhir hayatnya Pendidikan bisa didapatkan dimana saja, menurut Dalker (1974) pendidikan sepanjang hayat adalah perbuatan manusia secara wajar dan alami yang prosesnya tidak selalu memerlukan kehadiran guru, pamong, atau pendidik. Sedangkan menurut Gestrelius (1997) menggemukakan bahwa pendidikan sepanjang hayat mencakup interaksi belajar ( pembelajaran), penentuan 
bahan belajar dan metode belajar, lembaga penyelenggaraan, fasilitas, administrasi, dan kondisi lingkungan yang mendukung kegiatan belajar berkelanjutan. Adapun ciriciri pendidikan sepanjang hayat menurut Cropley (1997: 49) adalah: 1) sadar bahwa dirinya harus belajar sepanjang hayat, 2) memiliki pandangan bahwa belajar hal-hal yang baru merupakan cara logis untuk mengatasi masalah, 3) bersemangat tinggi untuk nbelajar untuk semua level, 4) menyambut baik perubahan, 5) percaya bahwa tantangan sepanjang hidup adalah peluang untuk belajar hal baru. Maka dari beberapa pendapat diatas pendidikan sepanjang hayat adalah sebagian besar pengalaman kehidupan sehari-hari bisa dijadikan sebuah pendidikan, karena bisa merubah seseorang untuk menjadi yang lebih baik.

Banyak lembaga yang menjadi tempat khusus untuk memberikan sebuah pendidikan, contohnya seperti sekolah mulai dari pendidikan dasar, pendidikan menengah pertama, dan pendidikan menengah atas, organisasi, lembaga kursus dan pelatihan serta perguruan-perguruan tinggi dan banyak lembagalainnya. Perguruan tinggi ataupun universitas menjadi wadah para pemuda pemu diuntuk membentuk karakter serta kepribadiannya lebih dewasa lagi. Saat memilih jurusan tak jarang calon mahasiswa hanya asal memilih jurusan tanpa melihat minat dan bakat yang sesuai dengan yang dimiliki, sehingga banyak mahasiswa merasa salah masuk jurusan. hal ini kerapkali terjadi di kalangan mahasiswa baru, salah satunya terjadi di universitas bengkulu. hal ini bisa dikarnakan kurangnya pemahaman calon mahasiswa dengan jurusan pendidikan nonformal. Melalui penelitian ini diharapkan dapat digunakan oleh program studi pendidikan nonformal untuk dijadikan dasar dalam merencanakan modal promosi. sehubungan dengan data sementara dari mahasiswa tersebut, dan kegunaan penelitian ini, maka penelitian ini dirasa penting untuk dilakukan.

\section{Metode}

Penelitian ini diarahkan pada gambaran yang bersifat deskriftif, Peneliti menggunakan metode penelitian kuantitatif dengan instrument penelitian berupa kuesioner. menurut Notoatmodjo dalam Afitri (2015: 23), metode deskrip kuantitatif adalah suatu metode penelitian yang dilakukan dengan tujuan utama untuk membuat gambaran tentang suatu keadaan secara objektif. Karena permasalahan yang ada dalam penelitian ini, menggambarkan dan menelaah tingkat pemahaman mahasiswa baru Pendidikan nonformal 
tentang program studi Pendidikan nonformal di Universitas Bengkulu tahun 2018. Adapun penelitian ini dilaksanakan tanggal6 Februari 2019. Teknik pengumpulan data menggunakan koesioner dengan membagikan koesioner kepada 25 orang subjek. Selanjutnya untuk teknik validitas data menggunakan ujivaliditas data, ujireabilitas data, analisis data, dan penarikan kesimpulan. Teknik validitas dipakai untuk mengecek kebenaran data. Teknik analisis data dalam penelitian ini meliputi seleksi data, klasifikasi data, tabulasi data, analisis dan interpretasi data. Seleksi data dilakukan dengan cara pemilihan terhadap data yang terkumpul untuk mendapat data yang sesuai dengan tujuan penelitian. Data yang diperoleh kemudian di analisis sehingga memperoleh data yang valid dan reliabel. Data yang disajikan dalam penelitian ini berupa table dan teksdeskriptif. Penarikan kesimpulan dalam penelitian ini yaitu berdasarkan hasil penelitian yang sudah diperoleh melalui koesioner. Penarikan kesimpulan disajikan oleh peneliti dalam bentuk deskripsi.

\section{Hasil dan Pembahasan}

Penelitian ini dilakukan pada mahasiswa baru kelas B prodi PNF di universitas bengkulu tahun ajaran 2018 yang berjumlah 25 orang. Waktu pelaksanaan penelitian dilakukan pada hari Senin 6 Februari 2019 di ruang 18 gedung belajar 3 Universitas Bengkulu.

Dengan menggunakan narasi dan tabel distribusi frekuensi. Untuk menentukan kriteria interprestasi tingkat pemahaman Pendidikan Nonformal oleh Mahasisawa baru yaitu menggunakan:

Angka 0\% - 20\% = sangat rendah Angka 21\% - 40\% = rendah Angka 41\%-60\% = cukup Angka 61\% - 80\% = tinggi Angka $81 \%-100 \%=$ sangat tinggi (Riduwan, 2013: 41).

1. Pemahaman mahasiswa baru tentang ruanglingkup pendidikan nonformal pada universitas Bengkulu.

a. Pemahaman mahasiswa baru tentang pengertian pendidikan nonformal

Tingkat pemahaman mahasiswa baru tentang Pendidikan Nonformal di Universitas Bengkulu dari hasil penelitian perhitungannya di peroleh rata-rata $=57 \%$, terletak pada sekala penilaian $41-60 \%$ dengan keterangan pemahaman yang tergolong cukup. pendidikan nonformal adalah pendidikan yang dilakukan di luar persekolahan biasa, penekanannya pada pendidikan yang berlangsung di luar sekolah. (Hasbullah, 2013:57).

Dari perhitungan ini maka dapat peneliti simpulkan bahwa tingkat 
pemehaman mahasiswa baru tentang Pendidikan Nonformal di Universitas Bengkulu sudah cukup paham. Karena sebagian besar mahasiswa memehami bahwa pendidikan nonformal merupakan pendidikan yang menaungi lembaga kursus dan karangtaruna dan Pendidikan Nonformal dapat dilakukan kapanpun ketika dibutuhkan. Hal ini sesuai berdasarkan undang-undang RI nomor 20 pasal 1 ayat 12 Dimana Pendidikan Nonformal adalah jalur pendidikan di luar pendidikan formal yang dapat dilakukan secara terstruktur dan berjenjang.

\section{b. Pemahaman mahasiswa baru tentang karakteristik pendidikan nonformal}

Tingkat pemahaman mahasiswa baru tentang karakteristik pendidikan nonformal di universitas dari hasil penelitian perhitungannya diperoleh rata-rata $=72,4 \%$, terletak pada skala 61 - $80 \%$ dengan keterangan pemahaman yang tergolong Tinggi.

Hal ini juga di jelaskan berdasarkan model yang digunakan Paulstor (1972), yang menyatakan karakteristik pendidikan nonformal sebgai berikut:
1) Tujuan: Jangka pendek dan khusus,dan Kurang menekankan pentingnya ijazah hasil belajar

2) Segi Waktu: Relatif singkat, Menekankan masa sekarang, dan Menggunakan waktu tidak terus menerus.

3) Isi program: Kurikulum berpusat pada kepentingan-kepentingan peserta didik, Mengutamakan aplikasi, dan Persyaratan masuk ditetapkan bersama peserta didik

4) Proses pembelajaran: Dipusatkan di lingkungan masyarakat dan lembaga, Berkaitan dengan kehidupan peserta didik dan masyarakat, Struktur program yang luwes, Berpusat pada peserta didik, dan Peghematan sumber-sumber yang tersedia

5) Pengendalian Dilakukan oleh pelaksana program dan peserta didik, dan melakukan Pendekatan demokratis.

c. Pemahaman mahasiswa baru tentang tujuan pendidikan nonformal

Tingkat pemahaman mahasiswa baru tentang tujuan Pendidikan Nonformal di Universitas Bengkulu dari hasil penelitian perhitungannya diperoleh rata-rata $=79 \%$, terletak pada sekala penilaian $61-80 \%$ dengan keterangan pemahaman yang tergolong Tinggi.

Dari perhitungan ini maka dapat peneliti simpulkan bahwa tingkat pemehaman mahasiswa baru tentang tujuan Pendidikan Nonformal di Universitas Bengkulu sudah paham, karena mereka mamahami dengan 
baik tujuan pendidikan nonformal hal ini sesuai dengan Undang-Undang RI nomor 20 tahun 2003 tentang dasar, fungsi dan tujuan pendidikan nasional, pasal 3 pendidikan nasional berfungsi mengembangkan kemampuan dan bentuk watak serta peradaban bangsa yang bermartabat dalam rangka mencerdaskan kehidupan bangsa, bertujuan untuk berkembangnya potensi peserta didik agar menjadi manusia yang beriman dan bertakwa kepada tuhan yang maha esa, berakhlak mulia, sehat, berilmu, cakap, kreatif, mandiri dan menjadi warga Negara yang demokratis serta bertanggung jawab.

\section{d. Pemahaman mahasiswa baru tentang peran pendidikan nonformal}

Tingkat pemahaman mahasiswa

baru tentang peran atau fungsi

Pendidikan Nonformal di Universitas

Bengkulu dari hasil penelitian perhitungannya di peroleh rata-rata $=$ $61,3 \%$, terletak pada sekala penilaian $61-80 \%$ dengan keterangan pemahaman yang tergolong Tinggi.

dari perhitungan ini maka dapat peneliti simpulkan bahwa tingkat pemehaman mahasiswa baru tentang peran Pendidikan Nonformal di
Universitas Bengkulu sudah paham, karena mereka telah memahami fungsi pendidikan nonformal. Hal ini sesuai dengan Undang-Undang RI nomor 20 tahun 2003 tentang pendidikan non formal pasal 26 ayat (2) pendidikan nonformal berfungsi mengembangkan potensi peserta didik dengan penekanan pada penguasaan pengetahuan dan keterampilan fungsional serta pengembangan sikap dan kepribadian professional.

\section{e. Pemahaman mahasiswa baru tentang program pendidikan nonformal}

Tingkat pemahaman mahasiswa

baru tentang program Pendidikan Nonformal di Universitas Bengkulu dari hasil penelitian perhitungannya di peroleh rata-rata $=72,4 \%$, terletak pada sekala penilaian $61-80 \%$ dengan keterangan pemahaman yang tergolong Tinggi.

Atas dasar perhitungan ini maka dapat peneliti simpulkan bahwa tingkat pemehaman mahasiswa baru tentang program Pendidikan Nonformal di Universitas Bengkulu sudah paham. Hal ini didasarkan Undang-Undang RI Nomor 20 tahun 2003 tentang pendidikan nonformal, pasal 26 ayat (3) pendidikan non 
formal meliputi pendidikan kecakapan hidup, pendidikan anak usia dini, pendidikan kepemudaan, pendidikan pemberdayaan perempuan, pendidikan keaksaraan, pendidikan keterampilan dan pelatihan kerja, pendidikan kesetaraan, serta pendidikan lain yang ditujukan untuk mengembangkan kemampuan peserta didik.

\section{f. Pemahaman mahasiswa baru tentang lembaga pendidikan nonformal}

Tingkat pemahaman mahasiswa

baru tentang lembaga Pendidikan Nonformal di Universitas Bengkulu dari hasil penelitian perhitungannya di peroleh rata-rata $=59 \%$, terletak pada sekala penilaian 41 - 60\% dengan keterangan pemahaman yang tergolong Cukup.

Dengan demikian maka dapat peneliti simpulkan bahwa tingkat pemehaman mahasiswa baru tentang lembaga Pendidikan Nonformal di Universitas Bengkulu sudah paham. hal ini Sebagaimana tercantum dalam UU No 20 Pasal 26 ayat 4 Tahun 2003 tentang Sistem Pendidikan Nasional, yang menyatakan bahwa : "Satuan pendidikan non formal terdiri atas lembaga kursus, lembaga pelatihan, kelompok belajar, pusat kegiatan belajar masyarakat, dan majelis taklim, serta satuan pendidikan yang sejenis".

\section{g. Pemahaman mahasiswa baru tentang sasaran pendidikan nonformal}

Tingkat pemahaman mahasiswa baru tentang sasaran Pendidikan Nonformal di Universitas Bengkulu dari hasil penelitian perhitungannya di peroleh rata-rata $=76,6 \%$, terletak pada sekala penilaian $61-80 \%$ dengan keterangan pemahaman yang tergolong Tinggi.

Dengan demikian dapat peneliti simpulkan bahwa tingkat pemehaman mahasiswa baru tentang sasaran Pendidikan Nonformal di Universitas Bengkulu sudah memahami sasaran pendidikan nonformal yang didasari atas dasar asas kebutuhan, asas pendidikan sepanjang hayat, asas relevansi dengan pembangunan, dan asas wawasan ke masa depan maka Sasaran pendidikan non formal tidak mengenal batasan usia, yaitu dari usia dini hingga lansia yang membutuhkan pendidikan berdasarkan kebutuhan belajarnya. Sasaran pendidikan nonformal yang mencakup semua lapisan masyarakat terutama masyarakat yang membutuhkan 
pendidikan, baik berupa ilmu pengetahuan maupun kecakapan hidup (Life Skills) sebagai penunjang untuk meningkatkan taraf hidup.

2. Pemahaman mahasiswa baru tentang kompetensi yang diperoleh lulusan pendidikan nonformal.

a. Pemahaman mahasiswa baru tentang kompetensi paedagogik pendidikan nonformal

Tingkat pemahaman mahasiswa

baru tentang kompetensi paedagogik

Pendidikan Nonformal di Universitas Bengkulu dari hasil penelitian perhitungannya di peroleh rata-rata $=$ $66 \%$, terletak pada sekala penilaian 61 - 80\% dengan keterangan pemahaman yang tegolong Tinggi.

Jadi, atas dasar perhitungan ini maka dapat peneliti simpulkan bahwa tingkat pemehaman mahasiswa baru tentang kompetensi paedagogik Pendidikan Nonformal di Universitas Bengkulu sudah paham. Hal ini Mengacu pada Kepmendiknas Nomor 232/U/2000, serta SK Mendiknas No. 045/U/2002, mengenai prospek bidang pekerjaan lulusan program studi S1 pendidikan nonformal/ pendidikan luar sekolah, menyebutkan bahwa:

Lulusan S1 Pendidikan Luar Sekolah memiliki kompetensi dalam mengelola dan mengembangkan program PLS/PNF serta fasilitator pembelajaran pada lembaga-lembaga PLS/PNFI, yang meliputi:

1) Pendidikan Anak Usia Dini (PAUD)

2) Pendidikan Orang Dewasa

3) Pendidikan Kepemudaan

4) Pendidikan Kesetaraan

5) Pendidikan Keaksaraan

6) Pendidikan Pemberdayaan Perempuan

7) Pendidikan Masyarakat dan Pelatihan Kerja Pendidikan dan Pelatihan yang lain yang ditujukan untuk mengembangkan kemampuan peserta didik (akademik, keterampilan-kewirausahaan) sesuai dengan kebutuhan. (Susanto, 2013).

\section{b. Pemahaman mahasiswa baru tentang kompetensi personal pendidikan nonformal}

Tingkat pemahaman mahasiswa baru tentang kompetensi personal Pendidikan Nonformal di Universitas Bengkulu dari hasil penelitian perhitungannya di peroleh rata-rata $=$ $28 \%$, terletak pada sekala penilaian 21 - 40\% dengan keterangan pemahaman yang Rendah.

Jadi, atas dasar perhitungan ini maka dapat peneliti simpulkan bahwa tingkat pemehaman mahasiswa baru tentang kompetensi personal Pendidikan Nonformal di Universitas Bengkulu tergolong rendah, para mahasiswa tidak memahami bahwa lulusan pendidikan nonformal 
memiliki kompetensi personal yang mencerminkan kepribadian yang mantap, stabil, dewasa, arif, dan berwibawa, menjadi teladan bagi peserta didik atau warga belajar, dan berakhlak mulia. Kepribadian tersebut adalah:

- Memiliki kepribadian yang mantap dan stabil

- Memiliki kepribadian yang dewasa

- Memiliki kepribadian yang arif

- Memiliki kepribadian yang berwibawa

- Memiliki pribadi yang mulia dan dapat menjadi teladan.

\section{c. Pemahaman mahasiswa baru tentang kompetensi sosial pendidikan nonformal}

Tingkat pemahaman mahasiswa

baru tentang kompetensi sosial

Pendidikan Nonformal di Universitas

Bengkulu dari hasil penelitian perhitungannya di peroleh rata-rata $=$ $82 \%$, terletak pada sekala penilaian 81

- $100 \%$ dengan keterangan pemahaman yang Sangat Tinggi.

Dalam hal ini maka dapat di simpulkan bahwa tingkat pemehaman mahasiswa baru tentang kompetensi sosial Pendidikan Nonformal di Universitas Bengkulu sudah paham. Mahasiswa sudah dapat memahami bahwa kompetensi Komepetensi sosial berkenaan dengan kemampuan pendidik sebaga bagian dari masyarakat untuk berkomunikasi dan bergaul secara efektif dengan peserta didik atau warga belajar, sesame pendidik, tenaga kependidikan, orang tua atau wali peserta didik, dan masyarakat sekitar. Kompetensi ini memiliki indicator sebagai berikut:

- Mampu berkomuniakasi dan bergaul sacara efektif dengan peserta didik atau warga belajar baik secara lisan maupun tulisan

- Mampu berkomunikasi dan bermitra secara efektif dengan sesama pendidik dan tenaga kependidikan.

- Mampu berkomunikasi dan bermitra secara efektif dengan orang tua/ wali peserta didik/ warag belajar dan masyarakat sekitar, sesuai dengan kebudayaan dan adat istiada.

\section{d. Pemahaman mahasiswa baru tentang kompetensi profesional pendidikan nonformal}

Tingkat pemahaman mahasiswa baru tentang kompetensi professional Pendidikan Nonformal di Universitas Bengkulu dari hasil penelitian perhitungannya di peroleh rata-rata $=$ $28 \%$, terletak pada sekala penilaian 21 - 40\% dengan keterangan pemahaman yang tergolong Rendah.

Dalam hal ini maka dapat di simpulkan bahwa tingkat pemehaman mahasiswa baru tentang kompetensi sosial Pendidikan Nonformal di 
Universitas Bengkulu masih belum begitu paham. Mahasiswa belum memahami Kompetensi profesional merupakan kemampuan yang berkenaan dengan penguasaan materi pembelajaran secara luas dan mendalam yang mencakup substansi isi materi kurikulum matapelajaran di satuan PNF dan subtansi keilmuan yang menaungi materi kulikulum tersebut, serta menambah wawasan keilmuan sebagai pendidik dan tenaga kependidikan pendidikan nonformal.

3. Pemahaman mahasiswa baru tentang kesempatan kerja yang diperoleh lulusan pendidikan nonformal

\section{a. Pemahaman mahasiswa baru tentang kesempatan kerja lulusan pendidikan nonformal secara umum}

Tingkat pemahaman mahasiswa

baru tentang kesempatan kerja lulusan Pendidikan Nonformal di Universitas Bengkulu secara umum dari hasil penelitian perhitungannya di peroleh rata-rata $=67 \%$, terletak pada sekala penilaian $61-80 \%$ dengan taraf pemahaman yang tergolong Tinggi.

Dengan demikian dapat penelitian simpulkan bahwa tingkat pemehaman mahasiswa baru dapat dikatakan sangat paham, karena mereka telah mamahami Bidang kerja secara umum dimaksud ini adalah bidang kerja yang pada umumnya ada di Indonesia. Menurut Notoatmodjo dalam Wawan dan Dewi (2010:138) jenis-jenis pekerjaan terbagi menjadi sebagai berikut:

1) Pedagang

2) Buruh / Tani

3) Pegawai Negeri Sipil

4) TNI/ Polri

5) Pensiunan

6) Wiraswasta

7) Ibu Rumah Tangga (IRT)

b. Pemahaman mahasiswa baru tentang kesempatan kerja lulusan pendidikan nonformal secara khusus

Tingkat pemahaman mahasiswa baru tentang kesempatan kerja lulusan Pendidikan Nonformal di Universitas Bengkulu secara khusus dari hasil penelitian perhitungannya di peroleh rata-rata $=68 \%$, terletak pada sekala penilaian $61-80 \%$ dengan keterangan taraf pemahaman yang tergolong Tinggi.

Dengan demikian dapat penelitian simpulkan bahwa tingkat pemehaman mahasiswa baru pendidikan nonfomal di universitas Bengkulu dapat dikatakan paham, karena mereka telah mamahami Bidang kerja secara khusus yang 
dimaksut ini adalah bidang kerja jurusan Pendidikan Nonformal yang pada umunya ada di Indonesia. Adapun bidang kerja lulusan Prodi Pendidikan Nonformal adalah sebagai berikut:

1) Dirjen PAUD dan DIKMAS Kemendikbud

2) Dirjen Pendidikan Dasar dan Menengah di Depdiknas

3) Pusat Pengembangan Pendidikan Anak Usia Dini Non Formal dan Informal (PP-PAUDNI)

4) Pamong belajar dan atau Birokrasi di Pusat Pengembangan Pendidikan Non Formal dan In Formal (P2-PNFI)

5) Pamong Belajar dan atau Birokrasi di Sanggar Kegiatan Belajar yang tersebar di Sanggar Kegiatan Belajar (SKB)

6) Tenaga Lapangan Dikmas (TLD) di Berbagai wilayah di Indonesia

7) Tenaga lapangan Pendidikan Masyarakat (DIKMAS)

8) engelola dan penyelenggara PNFI

9) Administrasi PNFI

10) Laboran PNFI

11) Lembaga kursus dan pelatihan

12) Pengelolaan kegiatan di berbagai lembaga kursus dan instruktur di lembaga kursus

13) Pengelola dan instruktur di Pusat Kegiatan Belajar Masyarakat (PKBM)

14) Tenaga perpustakaan di lembagalembaga pendidikan non formal da informal. Seperti TBM (Taman Bacaan Masyarakat), dll

\section{Penutup}

\section{a. Simpulan}

Sesuai dengan permasalahan, tujuan penelitian dan pembahasan maka rata - rata pemahaman tentang ruanglingkup pendidikan nonformal oleh mahasiswa baru pendidikan nonformal kelas B di universitas Bengkulu tahun 2018 adalah $69,4 \%$ yang berarti pemahaman termasuk dalam kategori Tinggi. Untuk rata-rata pemahaman tentang kompetensi yang diperoleh lulusan pendidikan nonformal oleh mahasiswa baru pendidikan nonformal kelas B di universitas Bengkulu tahun 2018 adalah $51 \%$ yang pemahaman termasuk dalam kategori Cukup, dan rata-rata pemahaman tentang kesempatan kerja dalam pendidikan nonformal oleh mahasiswa baru pendidikan non formal kelas B di universitas Bengkulu tahun 2018 adalah 67,5\% yang berarti pemahaman termasuk dalam kategori Tinggi. Rata - rata pemahaman mahasiswa baru tentang Pendidikan nonformal adalah 62,6\%. Maka persentase pemahaman mahasiswa secara keseluruhan merupakan sebagian besar dari mahasiswa memahami pendidikan nonformal.

\section{Refernsi}

Ahmadi, dan Nur Uhbiyati. 2015. Ilmu Pendidikan. Jakarta: Rineka Cipta 
Aliman. 2003. Konsep Pendidikan Luar

Sekolah. Bengkulu: Lemlit UNIB

Arikunto, Suharsimi. 2001. Prosedur penelitian suatu praktik pendekatan. Jakarta: Rineka Cipta. . 2002. Metodologi penelitian. Jakarta: Rineka Cipto 2006. ProsedurPenelitianSuatuPendekatanP raktik.Jakarta: PT. RinekaCipta. . 2009. Prosedur penelitian suatu ptaktik. Edisi revisi 6. Jakarta: Rineka Cipta.

ManajemenPenelitian. Jakarta: RinekaCipta

Dimayati dan Mudjiono. 2009. Belajar dan Pembelajaran. Jakarta: RinekaCipta

Hasbullah. 2013. Dasar-dasar Ilmu

Pendidikan. Jakarta: PT. Raja Grafindo Persada

kamil, mustofa. 2011. Pendidikan NonFormal Pengembangan Pusat Kegiatan Belajar Mengajar (PKBM) Di Indonesia (sebuah pembelajaran dari komunikan di jepang). Bangdung: Alfabeta.

Sudjana. 2010. Pendidikan Luar Sekolah :Wawasan, Sejarah Perkembangan, Falsafah Dan TeoriPendukung,
Serta Asas. Bandung: Falah Production Sugiyono. 2006. Metode Penelitian Kuantitatif Kualitatif dan $R \& D$. Bandung: Alfabeta

Sugiyono. 2017. Statistika Untuk Penelitian. Bandung: Alfabeta

Suprijanto. 2009. Pendidikan Orang Dewasa Dari Teori Hingga Aplikasi. Jakarta: PT. BumiAksara 